\title{
Penimbunan Alat Pelindung Diri pada Masa Pandemi Covid-19: Kajian Hukum Pidana Bidang Perlindungan Konsumen
}

\author{
Mohammad Faisol Soleh \\ Program Magister Ilmu Hukum Universitas Indonesia \\ faisolsoleh58@gmail.com
}

\begin{abstract}
One of the serious problems related to consumer protection during the current pandemic is the hoarding of Personal Protective Equipment (PPE) by certain business actors, causing its availability to become scarce and the price to skyrocket. This article discusses how the issue of PPE hoarding is assessed from the criminal law in the field of consumer protection. In this study, it is shown that, first, criminal law instruments have an important role in consumer protection law, because of the nature of the strict sanctions and can eradicate consumer violations. Although criminal law instruments on consumer protection apply as a last resort (ultimum remedium), there are reasons to treat them as primary (primum remedium), namely the pandemic situation and the urgency of the PPE itself in the situation. Second, criminal law instruments in the field of consumer protection can be used to crack down on PPE hoarding activities through the Trade Law and Business Competition Law. Criminal law provisions in the Trade Law can be used by establishing PPE as important goods because there is a prohibition on storing important goods in a certain amount and time when goods are scarce. The provisions of criminal law in the Business Competition Law can also be used if this hoarding is part of price-fixing, market control, or marketing of goods which results in monopolistic practices or unfair business competition.
\end{abstract}

Keywords: hoarding; personal protective equipment; covid-19; criminal law; consumer protection. 


\section{Abstrak}

Salah satu persoalan serius terkait perlindungan konsumen pada masa pandemi saat ini adalah adanya penimbunan Alat Pelindung Diri (APD) oleh oknum pelaku usaha tertentu, sehingga menyebabkan ketersediannya menjadi langka dan harganya pun melonjak mahal. Artikel ini membahas bagaimana persoalan penimbunan APD ini dikaji dari hukum pidana bidang perlindungan konsumen. Dalam kajian ini ditunjukkan, pertama, instrumen hukum pidana memiliki peranan penting dalam hukum perlindungan konsumen, karena sifat sanksinya yang tegas dan mampu memberantas pelanggaran konsumen. Meski instrumen hukum pidana pada perlindungan konsumen berlaku sebagai upaya terakhir (ultimum remedium), sesungguhnya terdapat alasan untuk memberlakukannya sebagai yang utama (primum remedium), yaitu situasi pandemi dan urgensi APD sendiri pada situasi tersebut. Kedua, instrumen hukum pidana bidang perlindungan konsumen dapat digunakan untuk menindak kegiatan penimbunan APD melalui UU Perdagangan dan UU Persaingan Usaha. Ketentuan hukum pidana dalam UU Perdagangan bisa digunakan dengan catatan harus menetapkan APD sebagai barang penting, sebab terdapat larangan menyimpan barang penting dalam jumlah dan waktu tertentu pada saat terjadi kelangkaan barang. Ketentuan hukum pidana dalam UU Persaingan Usaha juga bisa digunakan apabila penimbunan ini merupakan bagian dari penetapan harga, penguasaan pasar, atau pemasaran barang yang mengakibatkan praktik monopoli atau persaingan usaha tidak sehat.

Kata kunci: penimbunan; alat pelindung diri; covid-19; hukum pidana; perlindungan konsumen.

\section{A. Pendahuluan}

Artikel ini membahas penimbunan Alat Pelindung Diri (APD) pada masa pandemi covid-19 ditinjau dari hukum pidana bidang perlindungan konsumen. Pembahasan persoalan ini menjadi urgen setidaknya karena dua alasan: masifnya fenomena penimbunan APD pada saat pandemi dan perlunya instrumen hukum diberdayakan untuk menyelesaikan permasalahan penimbunan APD tersebut. Dalam artikel ini, instrumen hukum sebagaimana yang menjadi alasan kedua, difokuskan pada hukum pidana bidang perlindungan 
konsumen.

Pertama, tentang pandemi covid-19 dan fenomena penimbunan APD. Sebagaimana diketahui dunia saat ini tengah mengalami permasalahan sangat serius akibat munculnya virus baru yang ditemukan pertama kali pada sekitar Desember 2019 di Wuhan Provinsi Hubei, Tiongkok. ${ }^{1}$ Pasalnya, virus yang diberi nama oleh World Health Organization (WHO) sebagai Coronavirus Deseas (covid19) $)^{2}$ ini telah menyebarluas dan menginfeksi banyak orang di hampir seluruh belahan dunia. Lebih lagi, sampai saat ini metode ataupun obat dan vaksin untuk mencegah penularannya belum juga ditemukan. ${ }^{3}$ Penyebaran yang sangat cepat dari manusia ke manusia lainnya menyebabkan jenis virus baru ini juga ditetapkan sebagai pandemi global. ${ }^{4}$ Akibatnya, tidak hanya terhadap angka infeksi maupun kematian yang terus meningkat, fenomena tersebut juga telah berimbas pada hampir semua aspek kehidupan seperti ekonomi hingga hukum. Dibidang ekonomi, banyak negara telah menanggung beban ekonomi yang sangat serius dan akhirnya menimbulkan inflasi besar-besaran di semua lini. Dampak lebih lanjut akan terpuruknya ekonomi negara adalah sulitnya ekonomi masyarakat yang tidak jarang kemudian menimbulkan berbagai macam pelanggaran ekonomi baik secara individu bahkan secara masal guna memenuhi kebutuhan ekonominya di tengah wabah virus yang masih belum terhenti.

1 Adityo Susilo, dkk., "Corona Virus Deases 2019: Tinjauan Literatur Terkini”, Jurnal Penyakit Dalam Indonesia, 7, 1 (2020), hlm. 45.

2 Awal mula kemunculannya, virus ini disebut sebagai 2019 novel coronavirus (2019-nCoV), namun WHO memberikan nama baru baru pada 11 Februari 2020 sebagai Coronavirus Disease (COVID-19) yang disebabkan oleh virus Severe Acute Respiratory Syndrome Coronavirus-2 (SARS-CoV-2). Lihat Susilo, dkk., "Corona Virus Deases 2019", hlm. 45.

3 Serambinews.Com, "Vaksin Corona Masih Belum Ditemukan, Ini yang Terjadi di Dunia Jika Covid-19 Tak Bisa Dihentikan”, https://aceh. tribunnews.com/2020/05/08/vaksin-corona-maih-belum-ditemukan-iniyang-akan-terjadi-di-dunia-jika-covid-19-tak-bisa-dihentikan, 8/5/2020, diakses 10/6/2020.

4 World Health Organization, "WHO Timeline - COVID-19", https:// www.who.int/ news-room/detail/ 27-04-2020-who-timeline---covid-19, $27 / 4 / 2020$, diakses 10/6/2020. 
Indonesia sebagai salah satu negara terdampak covid-19 juga tidak terkecuali mengalami persoalan-persoalan tersebut. Beberapa sampel konkret di lapangan terkait dampak covid-19 di bidang ekonomi adalah banyaknya pelanggaran ekonomi yang merugikan serta telah melanggar etika dan hukum. Salah satu di antaranya adalah dalam bidang perlindungan konsumen, yaitu banyaknya produk dan kebutuhan ekonomi pada masa pandemi ini justru membuat sebagain orang menjadi panic buying, ${ }^{5}$ menimbun barang untuk keperluan pokok ataupun dijual dengan harga setinggi mungkin, dan lain sebagainya. Kondisi demikian memicu ketegangan di masyarakat sehingga mengakibatkan banyak masyarakat yang merasa membutuhkannya namun tidak dapat tercukupi karena kelangkaan barang yang ada.

Di antara barang yang mengalami kelangkaan dan sangat dibutuhkan masyarakat terutama tenaga medis adalah Alat Pelindung Diri (APD), yaitu suatu alat yang mempunyai kemampuan untuk melindungi seseorang yang fungsinya mengisolasi sebagian atau seluruh tubuh dari potensi bahaya. Di antara jenis APD adalah: penutup kepala, kacamata khusus, pelindung wajah, masker, sarung tangan, jas lab atau apron, pelindung kaki, dan coverall. ${ }^{6}$ Dalam masa pandemi covid-19, di antara APD yang mengalami kelangkaan ketersediaan barang dan harga yang tinggi akibat penimbunan oleh pihak tertentu, ialah masker, handsanitizer, dan alat kelengkapan medis lainnya. ${ }^{7}$ Hal ini jelas saja berdampak serius, karena barang-barang yang termasuk APD ini pada masa pandemi bukan hanya dibutuhkan tenaga medis yang bertugas langsung dalam penanggulangan pasien

5 Liputan6.Com, "Ketua Pusat Krisis: Panic BuyingMunculkarena Kecemasan Akan Wabah Corona COVID-19”, https://www.liputan6.com/health/ $\mathrm{read} / 4208375$ / ketua-pusat-krisis-panic-buying-muncul-karena-kecemasanakan-wabah-corona-covid-19, 22/3/2020, diakses 10/6/2020.

6 Lampiran Peraturan Menteri Kesehatan Republik Indonesia Nomor 52 Tahun 2018 tentang Keselamatan dan Kesehatan Kerja di Fasilitas Pelayanan Kesehatan.

7 Suara.Com, "Pandemi Covid-19:Jumlah APD Kurang, Tenaga Medis Rentan Terserang”, https:/ / www.suara.com/yoursay/2020/04/22/095442/ pandemi-covid-19-jumlah-apd-kurang-tenaga-medis-rentan-terserang, $22 / 4 / 2020$, diakses 10/6/2020. 
covid-19 sebagai orang paling retan terinfeksi, melainkan juga masyarakat umum. ${ }^{8}$ Minim dan mahalnya harga APD membuat sejumlah rumah sakit atau petugas medis lainnya sulit untuk dapat menjalankan tugasnya, ${ }^{9}$ sehingga tidak heran jika pekerja tersebut juga sebenarnya merugi sebagai konsumen.

Kedua, tentang kebutuhan instrumen hukum pidana dalam menyelesaikan persoalan penimbunan APD pada masa pandemi. Dalam suatu negara hukum, perlindungan hukum tentu saja diperlukan bagi seluruh warga, termasuk dalam kaitan artikel ini mereka yang dikategorikan sebagai konsumen. Oleh karenanya, instrumen hukum termasuk pidana bisa saja digunakan untuk mendukung perlindungan kepada konsumen. Masyarakat dan tenaga medis yang merupakan bagian dari subjek konsumen ${ }^{10}$ sudah seharusnya mendapatkan perlindungan hukum terkait ketersediaan kebutuhan APD. Kendati Undang-Undang Nomor 8 Tahun 1999 tentang Perlindungan Konsumen (UU Perlindungan Konsumen) tidak mengatur masalah penyalahgunaan APD ini, ketentuan dalam undang-undang lainnya yang juga memiliki tujuan perlindungan konsumen sebenarnyajuga dapat dikategorikansebagaibidanghukum perlindungan konsumen ${ }^{11}$ dan dapat diberlakukan terhadap persoalan penimbunan APD. Oleh karena penimbunan itu bermakna "proses, cara, perbuatan menimbun; pengumpulan" atau "kegiatan ilegal

8 Suara.Com, "Pandemi Covid-19".

9 VOAIndonesia.Com, "Stok APD Langka, Pekerja Medis di Sejumlah Daerah Pakai Jas Hujan”, https://www.voaindonesia.com/a/stok-apdlangka-pekerja-medis-di-sejumlah-daerah-pakai-jas-hujan/5356660.html, 2/4/2020, diakses 29/6/2020.

10 Berdasarkan Pasal 1 angka 2 UU Perlindungan Konsumen, konsumen adalah "setiap orang yang memakai barang dan/atau jasa yang ada di masyarakat baik untuk kepentingan sendiri maupun orang atau makhluk hidup lain serta tidak diperjual-belikan”.

11 Pasal 64 UU Perlindungan Konsumen tentang aturan peralihan: "Segala ketentuan peraturan perundang-undangan yang bertujuan melindungi konsumen yang telah ada pada saat Undang-undang ini diundangkan, dinyatakan tetap berlaku sepanjang tidak diatur secara khusus dan/atau tidak bertentangan dengan ketentuan dalam Undang-undang ini”. Lihat juga Yusuf Shofie, Perlindungan Konsumen dan Instrumen-intrumen Hukumnya (Bandung: Citra Aditya Bakti, cetakan kedua, 2003), hlm. 26. 
dalam mengumpulkan barang-barang yang dibatasi kepemilikannya oleh undang-undang," ${ }^{12}$ maka ketentuan perundang-undangan yang mengatur pembatasan dalam penyimpanan atau kepemilikan barang yang dimaksudkan untuk melindungi konsumen sesungguhnya dapat digunakan dan difungsikan untuk menindak penimbunan APD. Dalam konteks ini, ketentuan lainnya itu antara lain adalah Undang-Undang Nomor 7 Tahun 2014 tentang Perdagangan (UU Perdagangan) dan Undang-Undang Nomor 5 Tahun 1999 tentang Larangan Praktek Monopoli dan Persaingan Usaha Tidak Sehat (UU Persaingan Usaha).

Namun demikian, penggunaan ketentuan lainnya itu juga bukanlah persoalan yang mudah. Dalam UU Perdagangan misalnya, sebagaimana ketentuan Pasal 107, larangan berkaitan dengan penimbunan barang terkait pada barang pokok dan penting. Klasifikasi APD sebagai barang pokok ataupun penting sendiri telah menimbulkan perdebatan, dikarenakan baik UU maupun Peraturan Presiden Nomor 71 Tahun 2015 tentang Penetapan dan Penyimpanan Barang Kebutuhan Pokok dan Barang Penting (Perpres No. 71 Tahun 2015) sebagai aturan pelaksananya sama sekali tidak menyebutkan secara gamblang tentang barang yang dimaksud. Sedangkan pada UU Persaingan Usaha, penimbunan APD bisa saja bersinggungan dengan praktik monopoli dan penentuan harga yang tidak wajar. ${ }^{13}$ Kondisi demikian setidaknya membuktikan bahwa penimbunan APD oleh para oknum pelaku usaha ini memang telah menuai permasalahan serius, mengingat APD saat ini tidak hanya menjadi kebutuhan beberapa individu saja, melainkan kebutuhan semua masyarakat dan negara.

Berdasarkan alasan tersebut, artikel ini akan membahas penggunaan instrumen hukum pidana dalam menyelesaikan

12 Badan Pengembangan dan Pembinaan Bahasa Kementerian Pendidikan dan Kebudayaan Republik Indonesia, Kamus Besar Bahasa Indonesia, https: / / kbbi.kemdikbud.go.id/entri/penimbunan, diakses 28/6/2020.

13 Kompas.Com, "Cerita Gubernur Ganjar Kesal Ditawari Masker dan APD Harga Tak Wajar”, https://nasional.kompas.com/ $\mathrm{read} / 2020 / 05 / 09 / 16453841$ / cerita-gubernur-ganjar-kesal-ditawarimasker-dan-apd-harga-tak-wajar, 9/5/2020, diakses 10/6/2020. 
persoalan penimbunan APD pada saat pandemi covid-19, yang relatif belum banyak dibahas terlebih dalam jurnal. Ada artikel "Penerapan Sanksi Pidana bagi Penimbun Masker di Indonesia Selama Masa Pandemi Covid-19", namun pembahasannya terbatas pada APD berupa masker dan kajiannya juga dibatasi pada UU Perdagangan. ${ }^{14}$ Dalam artikel ini, persoalan penimbunan APD dikaji berdasarkan instrumen hukum pidana bidang perlindungan konsumen yang terdapat dalam UU Perdagangan dan UU Persaingan Usaha.

Dalam membahas aspek hukum pidana perlindungan konsumen pada penimbunan APD saat pandemi covid-19, artikel ini mengawalinya dengan penjelasan terlebih dahulu aspek hukum pidana dalam perlindungan konsumen. Kajian ini menganalisis keterkaitan hukum pidana dengan perlindungan konsumen, serta peran dan tujuan implementasi hukum pidana dalam menyelesaikan permasalahan pelanggaran perlindungan konsumen. Bagian berikutnya membahas ruang lingkup pengaturan pelanggaran pidana bidang perlindungan konsumen yang relevan diterapkan untuk menjerat pelaku penimbun APD pada masa pandemi covid-19. Kajian ini menganalisis dua ketentuan undang-undang yang secara materi muatan berisi perlindungan konsumen, yaitu UU Perdagangan dan UU Persaingan Usaha. Dengan ruang lingkup demikian, maka pada bagian akhir artikel diharapkan diperoleh kesimpulan tentang aspek hukum pidana apa saja dalam UU Perdagangan dan UU Persaingan Usaha yang dapat diberlakukan untuk menjerat pelaku penimbunan APD pada masa pandemi covid19.

\section{B. Aspek Hukum Pidana dalam Perlindungan Konsumen}

Hukum konsumen dan hukum perlindungan konsumen memang tidak dapat dipisahkan satu dengan lainnya. Selain karena keduanya sama-sama membahastentang persoalan konsumen, dikatakan bahwa hukum perlindungan konsumen merupakan salah satu bagian dari

14 Imas Novita Juaningsih, "Penerapan Sanksi Pidana bagi Penimbun Masker di Indonesia Selama Masa Pandemi Covid-19”, 'Adalah: Buletin Hukum dan Keadilan, 4, 1 (2020): 75-80. 
bahasan hukum konsumen. ${ }^{15}$ Hukum konsumen berpangkal pada pemaknaan sekumpulan asas-asas atau kaidah hukum tertentu yang mengatur tentang ekonomi baik terkait barang atau jasa konsumen ditinjau dari hubungan dan masalah antar berbagai pihak satu sama lain. Sedangkan hukum perlindungan konsumen ialah bentuk khusus tentang hukum konsumen yang menegaskan tentang bagaimana suatu hukum dilaksanakan guna menjamin kepastian dari pemenuhan perlindungan atas hak-hak konsumen. ${ }^{16} \mathrm{Hal}$ ini dapat juga dilihat dari makna eksplisit dalam UU Perlindungan Konsumen tentang definisi perlindungan konsumen, yaitu "segala bentuk upaya guna menjamin hadirnya kepastian dan perlindungan hukum terhadap konsumen". ${ }^{17}$

Secara umum, istilah hukum dapat digambarkan sebagai berbagai aturan-aturan dalam kehidupan masyarakat tentang tata cara bertingkah laku dan jika dilanggar akan dipaksakan pelaksanaannya melalui sanksi. ${ }^{18}$ Begitu juga dengan hukum perlindungan konsumen yang pada dasarnya merupakan salah satu bentuk pengejawantahan dari tujuan negara dalam Pembukaan Undang-Undang Dasar Negara Republik Indonesia Tahun 1945 (UUD NRI 1945) untuk mewujudkan perlindungan terhadap segenap warga negara dari perbuatan yang merugikan warga negara sebagai konsumen dari perilaku menyimpang pelaku usaha, sehingga hadirnya hukum perlindungan konsumen dalam konteks ini diharapkan mampu memberikan kesejahteraan bagi lingkup perekonomian konsumen sebagaimana konsepsi negara kesejahteraan yang termuat dalam konstitusi. ${ }^{19}$

Aspek penting dari hukum perlindungan konsumen adalah untuk menjamin kenyamanan masyarakat (konsumen) serta pelaku

15 Janus Sidabolok, Hukum Perlindungan Konsumen di Indonesia (Bandung: PT. Citra Aditya Bakti, 2010), hlm. 45.

16 Abdul Halim Barkatullah, Perlindungan Hukum bagi Konsumen Transaksi ECommerce Lintas Negara di Indonesia (Yogyakarta: FH UII Press, 2009), hlm. 13.

17 Pasa 1 angka 1 UU Perlindungan Konsumen.

18 Sudikno Mertokusumo, Mengenal Hukum (Yogyakarta: Universitas Atma Jaya Yogyakarta, 2010), hlm. 49.

19 Ali Mansyur dan Irsan Rahman, "Penegakan Hukum Perlindungan Konsumen Sebagai Upaya Peningkatan Mutu Produksi Nasional”, Jurnal Pembaharuan Hukum, 2, 1 (2015), hlm. 3. 
usaha akan berhati-hati dengan risiko hukum yang timbul dan secara tidak langsung akan berusaha memperbaiki untuk meningkatkan kualitas produksinya, hukum perlindungan konsumen hadir sebagai pembatas-pembatas bagi pelaku usaha dalam menjalankan bentuk usahanya. ${ }^{20}$ Ruang lingkup usaha dan pembatasan tersebut kemudian ditransformasikan ke dalam beberapa peraturan perundangundangan tentang ataupun putusan pengadilan dengan substansi perlindungan kepentingan konsumen. ${ }^{21}$ Lebih detail, hukum perlindungan konsumen adalah suatu kajian hukum ekonomi yang pembahasannya tidak lepas dari sudut pandang bidang hukum privat ataupun bidang hukum publik seperti hukum pidana dan hukum administrasi negara. ${ }^{22}$

Pada aspek hukum pidana, hukum perlindungan konsumen memainkan peran yang sangat signifikan dalam pencegahan dan pemberantasan pelanggaran konsumen. Hal ini terkait dengan ciri khusus hukum pidana yang juga disebut sebagai hukum sanksi, sehingga dapat digambarkan bahwa jika pelanggaran di bidang hukum ini terjadi, maka secara langsung akan berakibat pada penderitaan, nestapa, atau segala bentuk tidak menyenangkan lainnya secara badani. ${ }^{23}$ Dengan sanksi tegas yang mampu menyerang kepentingan hukum fundamental manusia, tidak heran jika hukum pidana sangat ditakuti dan dihindari oleh setiap orang. ${ }^{24}$ Kondisi demikian juga menjadikan aspek hukum pidana sangat penting bagi perlindungan konsumen, di mana konsumen dianggap memiliki posisi yang sangat lemah dengan dukungan hukum yang meningkat melalui instrumen hukum pidana mampu menjadi basis perlindungan mutakhir. ${ }^{25}$

20 Mansyur dan Rahman, "Penegakan Hukum Perlindungan Konsumen”, hlm. 3-4.

21 Inosentius Samsul, Perlindungan Konsumen: Kemungkinan Penerapan Tanggung Jawab Mutlak (Jakarta: Pascasarjana Fakultas Hukum Universitas Indonesia, 2004), hlm. 34.

22 Ahmadi Miru dan Sutarman Yado, Hukum Perlindungan Konsumen (Jakarta: RajaGrafindo Persada, 2004), hlm. 2.

23 Adami Chazawi, Pelanggaran Hukum Pidana (Jakarta: PT. Raja Grafindo Persada, 2008), hlm. 13.

24 Waluyadi, Hukum Pidana Indonesia (Jakarta: Djambatan, 2003), hlm. 29.

25 Krisztina Karsai, "Consumer Protection by Criminal Law”, dalam Ünnepi 
Hukum pidana perlindungan konsumen memang sedikit berbeda dengan bentuk pidana konvensional lainnya. Ia masuk dalam kategori mala prohibita yang menentukan bahwa sifat jahat dari tindakan pelanggaran perlindungan konsumen merupakan akibat dari ketentuan perundang-undangan yang menentukan demikian. ${ }^{26}$ Kondisi demikian menentukan bahwa sebenarnya aspekperlindungan konsumen merupakan bagian yang erat dari perkembangan delik tentang bagaimana suatu sifat jahatnya suatu perbuatan dapat pula dilihat tidak hanya melalui adanya akibat dan korban langsung secara fisik atas pelanggaran konsumen yang ada. ${ }^{27}$ Kedudukan hukum pidana memiliki peranan untuk memberlakukan hukum pidana sebagai alternatif penyelesaian permasalahan pelanggaran konsumen yang masuk dalam ranah pidana, karena pada prinsipnya di luar dari ketentuan hukum pidana tersebut, hukum konsumen dan hukum perlindungan konsumen merupakan bagian yang masuk dalam ranah hukum kontrak antara konsumen dengan pelaku usaha.

Meski demikian baik secara konsep, kondisi ini tidak selalu baik dalam pelaksanaannya di lapangan. Pasalnya, permasalahan yang seringkali dihadapi dalam pelanggaran di bidang ekonomi, termasuk juga perlindungan konsumen adalah, pertama, sulitnya menentukan korban dengan jelas, mengingat pelanggaran terhadap perlindungan konsumen cenderung bersifat abstract victims dan collective victims sehingga untuk mengidentifikasinya pun juga sulit, dan kedua, sukarnya melakukan penuntutan kepada para pelaku yang salah satunya adalah akibat dari sulitnya mengumpulkan barang bukti. ${ }^{28}$

Kondisi tersebut secara tidak langsung mengindikasikan bahwa memang penerapan hukum pidana dalam perlindungan konsumen masih menuai persoalan serius. Hal ini juga karena ketidaksamaan

ekönyv Herczeg János professzor 70. Születésnapjára, ed. Katona Tamás (Szeged: Szegedi Tudományegyetem Állam- és Jogtudományi Kar, 2012), hlm. 460.

26 Eddy O.S. Hiariej, Prinsip-Prinsip Hukum Pidana (Yogyakarta: Cahaya Atma Pustaka, 2014), hlm. 101-102.

27 Hiariej, Prinsip-Prinsip Hukum Pidana, hlm. 101-102.

28 Mardjono Reksodiputro, "Struktur Perekonomian Dewasa ini dan Permasalahan Korban”, makalah seminar Viktimologi, diselenggarakan oleh Universitas Airlangga, Surabaya, 28/10/1988, hlm. 5-6. 
antara nilai, kaidah dan pola perilaku di dalam suatu masyarakat yang akhirnya menimbulkan ketidakserasian pandangan manusia mengenai apa yang baik dan buruk terhadap suatu nilai tertentu. ${ }^{29}$ Perlindungan konsumen melalui hukum pidana memang masih dianggap belum efektif sepenuhnya, kondisi masyarakat yang masih menganggap pelanggaran terhadap perlindungan konsumen bukan merupakan suatu yang jahat sebagaimana sifat hukum pidana menandakan bahwa instrumen hukum pidana perlindungan konsumen belum ditempatkan secara baik dalam penegakan hukum perlindungan konsumen. Kendati demikian, dibandingkan dengan bidang hukum lain, hukum pidana merupakan bentuk sumber hukum terakhir yang memang seharusnya diterapkan sebagai upaya terakhir dalam penanggulangan bentuk pelanggaran pidana, ${ }^{30}$ termasuk pelanggaran di bidang konsumen.

Peran hukum pidana sebagai sarana terakhir tersebut menjadikan jenis hukum tersebut ditempatkan sebagai alternatif paling ampuh karena bidang hukum lain tidak efektif menanggulangi suatu permasalahan hukum tertentu. Terlebih, berbicara mengenai pelanggaran di bidang hukum pidana pada dasarnya telah masuk ke ranah hukum publik yang menempatkan negara untuk bertanggung jawab atas pelanggaran tersebut. ${ }^{31}$ Hukum pidana dalam perlindungan konsumen adalah bentuk konkret kontrol negara guna mewujudkan kesejahteraan warga negaranya melalui pemberdayaan konsumen untuk mendapatkan hak-haknya serta menciptakan iklim ekonomi yang dinamis dan positif. ${ }^{32}$

29 Hanafi Amrani, "Perlindungan Konsumen terhadap Praktik Bisnis Curang dan Upaya Penegakannya Melalui Sarana Hukum Pidana”, Negara Hukum, 6, 2 (2015), hlm. 200.

30 J.M.V. Bemmelen, Hukum Pidana I: Hukum Pidana Materiel Bagian Umum (Bandung: Bina Cipta, 1984), hlm. 13-16.

31 Ujang Charda S., "Telaah Kritis tehadap Inkonsistensi Konsep Hubungan Kerja dalam Undang-Undang Nomor 13 Tahun 2003 tentang Ketenagakerjaan”, Jurnal Wawasan Hukum, 33, 2 (2015), hlm. 121.

32 Abdul Halim Barkatullah, Hak-Hak Konsumen (Bandung: Nusa Media, 2010), hlm. 38 . 


\section{Penimbunan APD Saat Pandemi Covid-19 sebagai Pelanggaran Hukum Pidana Bidang Perlindungan Konsumen}

Dari pembahasan kedudukan dan peran hukum pidana dalam bidang perlindungan konsumen, diketahui bahwa instrumen hukum pidana menduduki peran penting dalam menjamin perlindungan hukum bagi konsumen. Urgensi demikian akan menjadi semakin krusial jika menilik situasi darurat seperti pada pandemi covid-19 yang tengah terjadi saat ini. Kehadiran hukum pidana dalam konteks ini diharapkan mampu mengatur kehidupan masyarakat yang memiliki kepentingan hidup berbeda-beda serta rentan terhadap pertentangan kepentingan atau menimbulkan kerugian dan menegasikan kepentingan-kepentingan tertentu, sehingga terwujudnya tertib umum sebagaimana seharusnya. ${ }^{33}$

Dalam situasi pandemi, penerapan hukum pidana dengan sanksi tegas menjadi sangat penting untuk diprioritaskan terhadap pelaku yang menimbun APD. Hukum pidana dapat saja memberikan peranan lebih dari sekadar pemberlakuannya dalam kondisi biasa dengan prinsip ultimum remedium, sebagaimana pembahasan terdahulu, melainkan berperan sebaliknya sebagai primum remedium atau upaya prioritas utama karena kondisi pandemi. Sebab, dalam situasi pandemi, keberadaan dan ketersediaan APD menjadi sangat penting bagi masyarakat dan bahkan negara. Pada kondisi demikian, istrumen hukum pidana relevan ditempatkan sebagai primum remedium terhadap pelanggaran di bidang perlindungan konsumen, mengingat bentuk pelanggaran tersebut sangat tercela ${ }^{34}$ dengan ancaman serius bagi keberlangsungan kehidupan manusia. ${ }^{35}$ Kondisi

33 Wirjono Prodjodikoro, Asas-asas Hukum Pidana di Indonesia (Bandung: Refika Aditama, 2003), hlm. 178.

34 Loebby Loqman, "Hukum Pidana di Bidang Perekonomian”, Jurnal Hukum dan Pembangunan, 24, 5 (1994), hlm. 369.

35 Hukum pidana pada dasarnya bertujuan untuk melindungi jiwa dan kehormatan manusia dan harta benda. Ketika suatu perbuatan telah menimbulkan dampak negatif terhadap kehidupan dan jiwa manusia, maka perbuatan tersebut harus dipandang sebagai perbuatan yang bertentangan dengan moral dan layak dikenai sanksi pidana, dan karenanya dalam hal 
dan situasi inilah yang memungkinkan untuk mengubah sifat hukum pidana yang semula ultimum remedium menjadi primum remedium, guna mengentaskan permasalahan penimbunan APD sebagai pelanggaran terhadap perlindungan konsumen.

Permasalahan penimbunan APD oleh beberapa oknum pelaku usaha sehingga menjadi langka dan dapat dijual di pasaran dengan harga yang di luar kewajaran, sebagaimana diuraikan dalam pendahuluan, menggambarkan bahwa pelanggaran tersebut tengah mengancam atau bahkan telah melanggar kepentingan masyarakat sebagai konsumen. Peranan negara melalui instrumen hukum pidana perlindungan konsumen dalam konteks ini dapat menjadi pilihan terbaik guna menyelesaikan pelanggaran pelaku usaha tersebut yang sebenarnya telah melanggar ketentuan hukum dan hak konsumen. Oleh karena dalam artikel ini, sebagaimana disampaikan pada bagian Pendahuluan, penimbunan dimaknai sebagai "proses, cara, perbuatan menimbun; pengumpulan" atau "kegiatan ilegal dalam mengumpulkan barang-barang yang dibatasi kepemilikannya oleh undang-undang", maka ketentuan perundang-undangan yang mengatur pembatasan pengumpulan atau kepemilikan barang yang dimaksudkan untuk melindungi konsumen tentu dapat digunakan dalam kaitannya dengan penimbunan APD. Dalam hal ini, ketentuan tentang penimbunan barang untuk kepentingan konsumen ini dilihat pada UU Perdagangan (UU Nomor 7 Tahun 2014) dan UU Persaingan Usaha (UU Nomor 5 Tahun 1999).

\section{UU Perdagangan}

UU Perdagangan merupakan UU yang mengatur kegiatan perdagangan, yaitu "tatanan kegiatan yang terkait dengan transaksi barang dan/atau jasa di dalam negeri dan melampaui batas wilayah negara dengan tujuan pengalihan hak atas barang dan/atau jasa untuk memperoleh imbalan atau kompensasi" ${ }^{36}$ Ini

ini hukum pidana menjadi yang utama (primum remedium). Lidya Suryani Widayati, "Ultimum Remedium dalam Bidang Lingkungan Hidup", Jurnal Hukum Ius Quia Iustum, 22, 1 (2015), hlm. 22.

36 Pasal 1 angka 1 UU Perdagangan. 
artinya, UU ini mengatur pula, dalam konteks permasalahan dalam artikel ini, kegiatan transaksi berkaitan dengan APD. Adanya aturan tentang perdagangan sendiri menunjukkan bahwa dalam kegiatan perekonomian termasuk perdagangan, peran pemerintah sesungguhnya mutlak, agar, antara lain, tersedianya barang-barang publik dan terhindarnya kegagalan pasar. ${ }^{37}$

Dalam kaitannya dengan penimbunan APD yang kemudian berdampak pada kelangkaan ketersediaannya dan harganya yang melambung tinggi, maka hal ini mengindikasikan tidak terwujudnya ketersediaan barang-barang publik sekaligus juga kegagalan pasar. Karena itu, intervensi pemerintah dalam soal ini menjadi sangat penting. Artikel ini tidak membahas intervensi pemerintah secara langsung dalam penyediaan APD, melainkan bagaimana instrumen hukum pidana dapat digunakan untuk menjerat pihak-pihak yang menyebabkan kegagalanketersediaan APD atau mekanisme pasarnya. Oleh karenanya, kegiatan-kegiatan yang memang dimaksudkan menghambat ketersediaan dalam perdagangan APD, perlu ditinjau lebih dalam UU Perdagangan.

Dalam UU Perdagangan, sesungguhnya ada ketentuan yang mengatur larangan kegiatan yang menyebabkan ketersediaan barang menjadi langka, yaitu ketentuan Pasal 107.

"Pelaku Usaha yang menyimpan Barang kebutuhan pokok dan/atau Barang penting dalam jumlah dan waktu tertentu pada saat terjadi kelangkaan Barang, gejolak harga, dan/atau hambatan lalu lintas Perdagangan Barang sebagaimana dimaksud dalam Pasal 29 ayat (1) dipidana dengan pidana penjara paling lama 5 (lima) tahun dan/atau pidana denda paling banyak Rp50.000.000.000,00 (lima puluh miliar rupiah)."

Ketentuan ini pada prinsipnya melarang pelaku usaha melakukan penyimpanan barang pokok maupun penting dalam jumlah dan kurun waktu tertentu pada saat mengalami kelangkaan, kenaikan harga, dan hambatan perdagangan. Kegiatan penyimpanan semacam itu biasanya juga disebut dengan ketentuan tentang larangan

37 EdySuandiHamid, "PerandanIntervensiPemerintah dalamPerekonomian”, Jurnal Ekonomi Pembangunan, 4, 1 (1999), hlm. 52. 
penimbunan barang.

Pemberlakuan ketentuan Pasal 107 UU Perdagangan untuk menjerat pelaku penimbunan APD ini memang bisa diperdebatkan. Hal ini karena dalam ketentuan tersebut yang dilarang adalah penyimpanan atau penimbunan "barang pokok atau penting". Mengenai barang pokok atau penting ini, diatur lebih lanjut dalam Perpres No. 71 Tahun 2015. Dalam Perpres ini, "barang kebutuhan pokok" dimaknai sebagai "barang yang menyangkut hajat hidup orang banyak dengan skala pemenuhan kebutuhan yang tinggi serta menjadi faktor pendukung kesejahteraan masyarakat", ${ }^{38}$ sedangkan "barang penting" dimaknai sebagai "barang strategis yang berperan penting dalam menentukan kelancaran pembangunan nasional" ${ }^{39}$ Perpres ini lalu secara limitatif menentukan barang pokok terdiri dari barang kebutuhan pokok hasil pertanian, hasil industri, serta hasil peternakan dan perikanan..$^{40}$ Sedangkan barang penting ditentukan pula secara limitatif pada benih padi, jagung, dan kedelai; pupuk; gas elpiji tiga kilogram; triplek; semen; besi baja kosntruksi; dan baja ringan..$^{41}$ Dalam kedua batasan yang limitatif itu, APD tidak ditemukan baik sebagai barang pokok maupun barang penting, sekalipun secara fungsional dalam masa pandemi covid1-9 saat ini jelas saja keberadaannya sangat pokok dan penting karena menyangkut keselamatan dan kesehatan masyarakat dan terutama tenaga medis.

Namun demikian, Perpres No. 71 Tahun 2015 sebenarnya masih memberi peluang bagi perluasan barang pokok dan penting. Sebab, ketentuan Pasal 2 ayat (7) mengatur bahwa jenis barang kebutuhan pokok dan penting yang telah ditetapkan secara limitatif itu dapat diubah berdasarkan usulan menteri setelah berkoordinasi dengan menteri atau kepala lembaga pemerintah nonkementerian terkait. Perubahan ini dikaitkan dengan keberadaan APD sebenarnya sangat mungkin dilakukan terutama untuk kategori barang penting. Pada Perpres ini disebutkan, penetapan jenis barang penting dilakukan

38 Pasal 1 angka 1 Perpres No. 71 Tahun 2015.

39 Pasal 1 angka 2 Perpres No. 71 Tahun 2015.

40 Pasal 2 ayat (6) huruf a Perpres No. 71 Tahun 2015.

41 Pasal 2 ayat (6) huruf b Perpres No. 71 Tahun 2015. 
berdasarkan sifat strategis dalam pembangunan nasional, ${ }^{42}$ yang memperhatikan ketentuan mendukung program pemerintah dan/ atau disparitas harga antardaerah tinggi. ${ }^{43}$

Oleh karena APD pada masa pandemi merupakan barang yang sangat dibutuhkan untuk menjaga kesehatan bahkan keselamatan masyarakat dan terutama tenaga medis, maka sudah sepatutnya ada perubahan terkait klasifikasi barang penting. Dalam situasi pandemi, tentu juga sudah menjadi program pemerintah untuk melakukan berbagai upaya yang mengurangi dan menghambat penyebaran virus yang belum ada obatnya ini. APD sendiri jelas sangat dibutuhkan dalam upaya mengurangi dan menghambat penyebarluasannya. Hal ini terbukti dari bukan saja anjuran, bahkan larangan untuk berada di ruang-ruang publik yang tidak menggunakan APD tertentu. Kondisi demikian sebenarnya patut untuk dijadikan dasar pijakan untuk mengklasifikasi APD sebagai salah satu jenis barang penting.

Dalam kaitan dengan penegakan hukum untuk menindak pelaku penimbunan APD, hal demikian mendorong dilakukannya penemuan hukum (rechtsvinding) maupun penafsiran oleh aparat penegak hukum. Kondisi tersebut tentu dapat mengacu pada salah satu Putusan Hogeraad pada 31 Januari 1919, yang memahami perbuatan melawan hukum sebagaimana dikenal dalam Pasal 1365 Kitab Undang-Undang Hukum Perdata (KUHPerdata) tidak hanya ditafsirkan sebagai perbuatan melawan hukum dalam bentuk yang telah tertulis (written) saja, melainkan juga yang tidak tertulis (unwritten). ${ }^{44}$ Dalam putusan pidana, hal ini tidaklah mudah karena prinsip hukum pidana dilandasi dengan asas legalitas. ${ }^{45}$ Asas ini menjadi sangat fundamental dengan salah satu ciri khususnya yaitu larangan menggunakan analogi, ${ }^{46}$ artinya setiap aparat penegak hukum dalam hal menegakkan hukum pidana tidak boleh membuat penafsiran yang diluar dari maksud pembuat undang-undang atau

42 Pasal 2 ayat (4) Perpres No. 71 Tahun 2015.

43 Pasal 2 ayat (5) Perpres No. 71 Tahun 2015.

44 R. Soeroso, Pengantar Ilmu Hukum (Jakarta: Sinar Grafika, 1996), hlm. 257.

45 Roelof H. Haveman, The Legality of Adat Criminal Law in Modern Indonesia (Jakarta, Tata Nusa, 2002), hlm. 50.

46 Heveman, The Legality of Adat Criminal Law, hlm. 50. 
menyamakannya pada suatu yang sebenarnya tidak sama dengan suatu lainnya. ${ }^{47}$

Kendati demikian, penemuan hukum tetap dapat dilaksanakan jika memang terdapat suatu sifat melawan hukum yang ada pada tindakan pelanggaran tersebut. Sifat melawan hukum ini dalam suatu tindak pidana diartikan dengan merujuk pada argumentasi bahwa suatu tindakan dapat disebut tindak pidana jika sifat tindakan (wesen) tersebut "dem Wesen nach" sejalan dengan maksud dari ketentuan hukum pidana yang dimaksudkan. ${ }^{48}$ Kondisi demikian yang menjadi dasar bagi aparat penegak hukum untuk menggunakan pertimbangan hukum dengan menggunakan tafsir sistematik sebagai jalan tengahnya, yaitu penafsiran yang menitikberatkan pada keseragaman ketentuan perundang-undangan lainnya yang mengatur hal sama. ${ }^{49}$ Landasan ini juga yang tampaknya menjadi dasar terbitnya Peraturan Menteri Perdagangan Nomor 34 Tahun 2020 tentang Perubahan Kedua Atas Peraturan Menteri Perdagangan Nomor 23 Tahun 2020 tentang Larangan Sementara Ekspor Antiseptik, Bahan Baku Masker, Alat Pelindung Diri dan Masker, yang telah mengakomodasi larangan ekspor APD akibat kondisi barang yang semakin tidak stabil saat pandemi covid-19. Pengaturan tersebut secara tidak langsung menegaskan bahwa penafsiran terhadap APD sebagai barang penting sebagaimana ketentuan dalam UU Perdagangan bukanlah suatu analogi, melainkan suatu tafsir sistematis atas maksud ketentuan perundang-undangan yang mengatur hal serupa. Hal demikian juga selaras dengan maksud diakomodasinya ketentuan penetapan barang penting sebagaimana diatur dalam Perpres No. 71 Tahun 2015, yang menjelaskan bahwa penetapan barang penting didasarkan atas sifat barang yang dianggap strategis dalam pembangunan nasional. Kesamaan maksud inilah yang juga secara tidak langsung menegaskan kembali bahwa APD memang layak dimaknai sebagai

47 Heveman, The Legality of Adat Criminal Law, hlm 50.

48 E. Utrecht, Hukum Pidana I (Surabaya: Pustaka Tinta Mas, 1986), hlm. 261263.

49 Afif Khalid, "Penafsiran Hukum oleh Hakim dalam Sistem Peradilan di Indonesia”, Al-Adl: Jurnal Hukum, 6, 11 (2014), hlm. 17. 
salah satu barang penting saat pandemi covid-19.

Namun demikian, memperjelas ketentuan perundang-undangan menjadi kebijakan yang sistematis juga seharusnya menjadi prioritas untuk menetapkan APD sebagai bagian dari barang penting. Peraturan Menteri Perdagangan tersebut telah jelas mengakomodasi ketentuan tentang larangan ekspor APD karena kebutuhan dan kepentingan masyarakat serta negara akan barang tersebut, sehingga bukan tidak berarti dengan berbagai pertimbangan dan gejolak yang terjadi akibat pelanggaran konsumen atas APD yang ditimbun atau disalahgunakan oleh pelaku usaha. Ketentuan tersebut disesuaikan untuk merevisi jenis barang pokok dan penting dengan usulan menteri setelah berkoordinasi dengan menteri atau kepala lembaga pemerintah non-kementerian terkait. Menteri Perdagangan melalui peraturannya sebenarnya dapat mendorong kejelasan kedudukan APD sebagai barang penting dengan mengubah aturan tentang jenis barang tersebut. Karena itu, bukan tanpa alasan, kategorisasi APD sebagai barang penting pada saat pandemi covid-19 ini mampu menyelesaikan abstraknya penegakan hukum pidana perlindungan konsumen bagi pelaku usaha yang menimbun APD sebagai salah satu jenis barang penting.

\section{UU Persaingan Usaha}

UU Persaingan Usaha, atau nomenklatur lengkapnya adalah UU Larangan Praktek Monopoli dan Persaingan Usaha Tidak Sehat, ${ }^{50}$ merupakan UU yang bertujuan untuk menjaga kepentingan umum, mewujudkan iklim usaha yang sehat, mencegah praktik monopoli dan pesaingan usaha tidak sehat, serta terciptanya efektivitas dan efisiensi dalam kegiatan usaha. ${ }^{51}$ Dengan demikian, UU Persaingan Usaha menghendaki agar kegiatan usaha berlangsung secara sehat,

50 Dalam artikel ini, kata "praktek" digunakan untuk menunjukkan nomenklatur ketentuan persaingan usaha, yaitu "Larangan Praktek Monopoli dan Persaingan Usaha Tidak Sehat”. Sedangkan selebihnya, jika tidak dimaksudkan untuk menyebut nomenklatur peraturan, kata "praktik" yang digunakan karena alasan kebakuannya.

51 Pasal 3 UU Persaingan Usaha. 
sehingga praktik-praktik monopoli dan berbagai kecurangan dalam berusaha harus dicegah supaya tidak mengganggu kepentingan umum.

Dalam kaitannya dengan permasalahan dalam artikel ini, yaitu penimbunan APD, maka UU Persaingan Usaha relevan digunakan manakala penimbunan tersebut termasuk ke dalam bentuk praktik monopoli dan persaingan usaha tidak sehat. Dalam UU Persaingan Usaha, ada 10 jenis perjanjian dan enam kegiatan yang dikategorikan dilarang. Meskipun demikian, dalam konteks bahasan artikel ini tidak seluruh perjanjian dan kegiatan yang dilarang itu relevan, dan karenanya bagian berikut hanya membahas larangan perjanjian dan kegiatan yang memiliki relevansi.

Pertama oligopoli. Larangan oligopoli ini mengacu pada Pasal 4 Ayat (1) UU Persaingan Usaha, "Pelaku usaha dilarang membuat perjanjian dengan pelaku usaha lain untuk secara bersama-sama melakukan penguasaan produksi dan atau pemasaran barang dan jasa yang dapat mengakibatkan terjadinya praktek monopoli dan atau persaingan usaha tidak sehat." Ketentuan ini dalam hukum persaingan usaha kemudian dikenali sebagai perjanjian oligopoli, yaitu perjanjian yang menciptakan stuktur pasar, di mana di dalam pasar tersebut hanya terdiri dari sedikit pelaku usaha, sehingga mempengaruhi harga pasar dan perilaku perusahaan lainnya. Karena adanya saling mempengaruhi itu, maka dalam pasar oligopoli telah terjadi interdependensi antar pelaku usaha yang bersaing, yang memaksa pelaku usaha untuk mempertimbangkan reaksi pesaingnya ketika membuat suatu keputusan dalam menetapkan harga jual. ${ }^{52}$

Namun demikian, perjanjian oligopoli sendiri merupakan ketentuan yang rule of reason, yang artinya perjanjiannya sendiri tidaklah dilarang selama tidak mengakibatkan praktik monopoli atau persaingan usaha tidak sehat. ${ }^{53}$ Dalam UU Persaingan Usaha

52 Daniel Agustino, "Karakteristik Harga dan Pengawasan KPPU terhadap Industri Oligopoli”, Jurnal Persaingan Usaha, 3 (2010), hlm. 16-17.

53 Andi Fahmi Lubis, dkk, Hukum Persaingan Usaha: Buku Teks, ed. Ningrum Natasya Sirait, Andi Fahmi Lubis, dan Helena Wirastri Wulandari (Jakarta: Komisi Pengawas Persaingan Usaha, 2017), hlm. 92.93. 
disebutkan, situasi oligopoli ini patut diduga terjadi jika dua atau tiga pelaku usaha atau kelompok pelaku usaha menguasai lebih dari 75 persen pangsa pasar satu jenis barang. ${ }^{54}$ Dalam kaitannya dengan penimbunan APD, maka oligopoli patut diduga terjadi apabila 75 persen penguasaan produksi dan atau pemasaran APD ternyata dikuasai oleh kelompok pelaku usaha tertentu, yang kemudian mengakibatkan praktik monopoli atau persaingan usaha tidak sehat.

Kedua, perjanjian penetapan harga. Larangan ini mengacu pada Pasal 5 ayat (1) UU Persaingan Usaha, "Pelaku usaha dilarang membuat perjanjian dengan pelaku usaha pesaingnya untuk menetapkan harga atas suatu barang dan atau jasa yang harus dibayar oleh konsumen atau pelanggan pada pasar bersangkutan yang sama”. Dalam persaingan usaha, perjanjian penetapan harga (price fixing agreement) merupakan salah satu strategi yang dilakukan oleh pelaku usaha dalam mendapatkan keuntungan yang sebesar-besarnya, ${ }^{55}$ yang dengan demikian jelas mengabaikan keseimbangan kepentingan pelaku usaha lainnya serta masyarakat selaku konsumen. ${ }^{56}$ Ketentuan larangan ini sendiri dalam hukum persaingan usaha termasuk sebagai per seillegal, yang berarti tidak perlu dibuktikan apakah menimbulkan praktik monopoli atau persaingan usaha tidak sehat atau tidak, yang terpenting dibuktikan telah ada kesepakatan tentang harga yang harus dibayar konsumen.

Dalam kaitannya dengan penimbunan APD, ketentuan larangan penetapan harga ini dapat dikenakan apabila penimbunan APD yang terjadi pada masa pandemi ini ternyata bagian dari suatu kesepakatan penetapan harga APD yang harus dibayar konsumen. Hal ini mungkin mengingat ketersediaan APD sendiri kemudian menjadi langka, dan tatkala ada, harga untuk memerolehnya menjadi sangat mahal.

Ketiga, kartel.Larangan ini mengacu pada Pasal 11 UUPersaingan

54 Pasal 4 ayat (2) UU Persaingan Usaha.

55 Lubis, dkk, Hukum Persaingan Usaha, hlm. 95.

56 Azizah, "Konsep Pengembangan Pendekatan Struktural dalam Perjanjian Penetapan Harga pada Putusan KPPU”, Jurnal Hukum dan Pembangunan, 43, 4 (2013), hlm. 519. 
Usaha, "Pelaku usaha dilarang membuat perjanjian dengan pelaku usaha pesaingnya, yang bermaksud untuk mempengaruhi harga dengan mengatur produksi dan atau pemasaran suatu barang dan atau jasa, yang dapat mengakibatkan terjadinya praktek monopoli dan atau persaingan usaha tidak sehat". Dalam ketentuan ini, maka kartel berarti bisa berupa pengaturan produksi ataupun pemasaran suatu barang. Dikaitkan dengan aktivitas penimbunan APD, maka bisa jadi hal itu terkait pengaturan produksi, namun lebih besar kemungkinannya dalam pemasarannya.

Namun demikian, ketentuan kartel dalam Pasal 11 itu sesungguhnya ketentuan yang bersifat rule of reason. Hal ini dikarenakan terdapatnya kata "dapat mengakibatkan" di sana, yang berarti perjanjian ini menjadi terlarang apabila menimbulkan akibat praktik monopoli atau persaingan usaha tidak sehat. Apabila tidak menimbulkan praktik monopoli atau persaingan usaha tidak sehat, berarti perjanjiannya tidaklah dilarang.

Keempat, monopoli. Larangan ini merujuk pada Pasal 17 ayat (1) UU Persaingan Usaha, "Pelaku usaha dilarang melakukan penguasaan atas produksi dan atau pemasaran barang dan atau jasa yang dapat mengakibatkan terjadinya praktek monopoli dan atau persaingan usaha tidak sehat". Larangan monopoli ini berbeda dengan tiga larangan sebelumnya yang merupakan bagian dari perjanjian yang berarti pasti melibatkan lebih dari satu pelaku usaha, melainkan dapat dilakukan oleh satu pelaku usaha atau satu kelompok pelaku usaha. Satu pelaku usaha atau satu kelompok pelaku usaha patut diduga melakukan monopoli ini jika, antara lain, menguasai lebih dari 50 persen pangsa pasar satu jenis barang atau jasa tertentu. ${ }^{57}$ Karena ada kata "dapat mengakibatkan", maka ketentuan ini termasuk rule of reason, yang berarti penguasaan tersebut harus berdampak pada praktik monopoli atau persaingan usaha tidak sehat.

Agar ketentuan kartel ini dapat dikenakan untuk menindak aktivitas penimbunan APD, maka ada dua hal yang harus dipenuhi. Pertama, pelaku penimbunan ini merupakan satu pelaku usaha

57 Pasal 17 ayat (2) huruf c UU Persaingan Usaha. 
atau satu kelompok pelaku usaha yang menguasai produksi atau pemasaran APD (tertentu) yang mencapai lebih 50 persen. Kedua, penimbunan ini mengakibatkan praktik monopoli atau pesaingan suaha tidak sehat.

Kelima, penguasaan pasar. Larangan ini didasarkan pada Pasal 19 UU Persaingan Usaha, yang melarang pelaku usaha, baik sendiri maupun bersama pelaku usaha lainnya, melakukan satu atau beberapa kegiatan yang dapat mengakibatkan terjadinya praktik monopoli atau persaingan usaha tidak sehat berupa, salah satunya, membatasi peredaran dan atau penjualan barang dan atau jasa pada pasar bersangkutan. Dalam ketentuan ini, yang dilarang adalah penguasaan pasar berupa, salah satunya dan ini yang relevan dengan penimbunan APD, pembatasan peredaran dan atau penjualan barang, yang berakibat praktik monopoli atau persaingan usaha tidak sehat. Oleh karena ada implikasi yang harus dibuktikan terlebih dahulu, maka ketentuan ini tergolong sebagai rule of reason.

Dalam kaitannya dengan penimbunan APD, maka sangat mungkin ketentuan larangan penguasaan pasar berupa pembatasan peredaran atau penjualan ini untuk diberlakukan. Sebab, ketersediaan APD selama masa pandemi ini terindikasi terbatas pada pihak terutama pedagang tertentu, yang kemudian jelas menimbulkan praktik monopoli atau persaingan usaha tidak sehat.

Oleh karena akan sangat kasuistik, maka artikel ini tentu saja tidak punya kapasitas untuk menentukan larangan perjanjian dan kegiatan mana dari lima yang dibahas di sini yang tepat digunakan untuk menindak penimbunan APD pada masa pandemi. Sebab, kelimanya memiliki karakteristik pelanggaran tersendiri, terutama pada tiga pertama yang mensyaratkan adanya perjanjian sekalipun barangkali tidak secara tertulis, sedangkan pada dua terakhir merupakan kegiatan yang berarti bisa saja dilakukan oleh satu pelaku usaha atau satu kelompok pelaku usaha. Pada tiga yang pertama, karena harus ada kesepakatan, sering pula di masyarakat disebut sebagai kartel, sekalipun secara yuridis berbeda. ${ }^{58}$ Demikian pula,

58 Hal ini tidak sepenuhnya keliru, karena kartel memang bisa diartikan secara sempit maupun luas. Dalam arti sempit, kartel adalah perjanjian 
dari kelima larangan tersebut, hanya perjanjian penetapan harga yang tergolong sebagai pelanggaran yang cukup dibuktikan dengan adanya kesepakatan saja, sementara selebihnya, selain harus ada perjanjian atau kegiatan tertentu yang bisa dibuktikan, juga masih memerlukan pembuktian berikutnya berupa akibat praktik monopoli atau persaingan usaha tidak sehat yang ditimbulkannya.

Dari aspek hukum pidana, kelima larangan tersebut juga termasuk sebagai larangan yang dapat diancam pidana. Larangan oligopoli, kartel, monopoli, dan penguasaan pasar, berdasarkan Pasal 48 ayat (1) UU Persaingan Usaha diancam pidana denda 25 sampai 100 miliar rupiah, atau pidana kurungan pengganti denda maksimal enam bulan. Untuk larangan perjanjian penetapan harga, berdasarkan Pasal 48 ayat (2) diancam pidana denda 5 sampai 25 miliar rupiah, atau pidana kurungan pengganti denda maksimal lima bulan. Perbedaan ancaman pidana pada perjanjian atau kegiatan yang dilarang ini tampaknya dibedakan antara yang tergolong sebagai rule of reason atau per se illegal. Oligopoli, kartel, monopoli, dan penguasaan pasar tergolong sebagai rule of reason, sedangkan larangan perjanjian penetapan harga tergolong sebagai per se illegal.

Instrumen hukum pidana dalam UU Persaingan Usaha ini urgen dan relevan digunakan untuk menindak pelaku penimbunan APD pada saat covid-19. Sebab, perilaku penimbunan ini tidak hanya berkaitan dengan hak masyarakat yang telah dilanggar, namun juga negara yang tengah genting akan kebutuhan APD pada saat covid-19. Ketersediaan APD dan keterjangkauan kepemilikannya dengan demikian turut berpengaruh pula pada kesehatan bahkan keselamatan masyarakat. Bagi negara, penimbunan APD yang berdampak pada kelangkaan dan harga mahal ini tentu menghambat tugas dan tanggung jawab negara dalam memenuhi hak asasi manusia dan hak konstitusional warganya mendapatkan hak atas kesehatan

sekelompok perusahaan yang seharusnya saling bersaing untuk menetapkan harga guna meraih keuntungan monopolistis; sedangkan dalam arti luas, kartel meliputi perjanjian antara para pesaing untuk membagi pasar, mengalokasikan pelanggan, dan menetapkan harga. Anna Maria Tri Anggraini, "Penggunaan Bukti Ekonomi dalam Kartel Berdasarkan Hukum Persaingan Usaha”, Jurnal Hukum Prioris, 3, 3 (2013), hlm. 2-3. 
dan pelayanan kesehatan. ${ }^{59}$

Ketentuan pidana dalam UU Persaingan Usaha sebagaimana telah dibahas terlihat hanya mengakomodasi sanksi pidana pokok berupa denda atau kurungan sebagai gantinya. Ini artinya, pelanggaran monopoli dan persaingan usaha tidak sehat tidak dikenakan pidana pokok penjara, yang ukuran dampak jeranya terhadap pelaku individu sebenarnya sangat signifikan, khususnya untuk melindungi masyarakat dan perbaikan pelaku sendiri. ${ }^{60}$

Kendati terdapat kelemahan tersebut, upaya lain dari aspek hukum pidana sebenarnya dapat ditempuh untuk menindak penimbunan APD, yaitu melalui penerapan ketentuan pidana tambahan selain pidana pokok. UU Persaingan Usaha sendiri mengakomodasi beberapa ketentuan pidana tambahan untuk diterapkan pada keseluruhan pelanggaran pidana atas praktik monopoli dan persaingan usaha tidak sehat, yaitu meliputi:

a. pencabutan izin usaha; atau

b. larangan kepada pelaku usaha yang telah terbukti melakukan pelanggaran terhadap undang-undang ini untuk menduduki jabatan direksi atau komisaris sekurang-kurangnya 2 (dua) tahun dan selamalamanya 5 (lima) tahun; atau

c. penghentian kegiatan atau tindakan tertentu yang menyebabkan timbulnya kerugian pada pihak lain." ${ }^{11}$

Pada prinsipnya, penerapan ketentuan pidana tambahan bersifat alternatif. Ia bukanlah sanksi yang wajib dijatuhkan, atau hanya merupakan suatu opsi jika pidana pokok dianggap kurang. Meski begitu, bukan berarti kedudukan sanksi pidana tambahan tidak begitu penting untuk dijatuhkan, karena pidana tambahan sebenarnya

59 Hak atas kesehatan merupakan isu krusial dalam hak asasi manusia dan hak konstitusional rakyat, dan karenanya menuntut peran aktif negara untuk mewujudkannya sebagai bagian dari pelaksanaan hak-hak ekonomi, sosial, dan budaya. Rico Mardiansyah, "Dinamika Politik Hukum dalam Pemenuhan Hak atas Kesehatan di Indonesia”, Veritas et Justitia, 4, 1 (2018), hlm. 247.

60 Barda Nawawi Arief, Bunga Rampai Kebijakan Hukum Pidana (Bandung: Citra Aditya Bakti, 1996), hlm. 246.

61 Pasal 49 UU Persaingan Usaha. 
memiliki karakteristik khusus dengan tujuan preventif atau pencegahan yang hendak dicapai terhadap tindakan pelanggaran. ${ }^{62}$ Tindak pidana dalam persaingan usaha sendiri merupakan tindak pidana bermotifkan ekonomi, yang berarti analisis ekonomi terhadap hukum mampu menjadi alternatif untuk melihat sanksi pidana yang sesuai untuk pelaku monopoli, yaitu dengan mempertimbangkan berbagai prinsip seperti nilai (value), kegunaan (utility) dan efisiensi (efficiency), ${ }^{63}$ serta dampaknya terhadap masyarakat serta negara guna mewujudkan sebesar-besarnya kebahagiaan. ${ }^{64}$ Dengan demikian, pidana pokok maupun pidana tambahan sesungguhnya dapat samasama diberlakukan secara proporsional dan efektif. Hal ini juga karena sebenarnya penjatuhan baik pidana pokok sekaligus pidana tambahan tidak hanya dilakukan berdasarkan faktor pertimbangan yuridis semata, melainkan juga faktor non-yuridis seperti halnya aspek sosiologis, psikologis, kriminologis dan bahkan juga ekonomi. ${ }^{65}$ Karena itu, motif ekonomi dan situasi pandemi covid-19 yang sedang berlangsung, sesungguhnya menjadi alasan kuat bagi pemberlakuan pidana pokok dan tambahan secara sekaligus dalam penindakan penimbunan APD yang memang dapat membahayakan kesehatan dan bahkan keselamatan masyarakat.

\section{Kesimpulan}

Artikel ini menyimpulkan, pertama, instrumen hukum pidana dalam perlindungan konsumen memiliki peranan penting dalam menyelesaikan permasalahan pelanggaran perlindungan konsumen. Hukum pidana yang dianggapjuga sebagai hukum sanksi memberikan konsekuensi nestapa dan penderitaan bagi pelaku pelanggaran. Kendati demikian penerapan hukum pidana bidang perlindungan konsumen masih menuai persoalan, selain karena sifatnya yang

62 Roeslan Saleh, Stelsel Pidana Indonesia (Jakarta: Aksara Baru, 1983), hlm. 19.

63 Richard A. Posner, Economic Analysis of Law (Boston: Little Brown and Company, edisi keempat, 1992), hlm. 11-15.

64 K. Bertens, Pengantar Etika Bisnis (Yogyakarta: Kanisius, 2000), hlm. 66.

65 Rusli Muhammad, Hukum Acara Pidana Kontemporer (Bandung: PT Citra Aditya Bakti, 2007), hlm. 212. 
merupakan hukum terakhir, juga karena cenderung menghasilkan abstract dan collective victims serta sulitnya mengumpulkan alat bukti untuk penuntutan. Meski belum sepenuhnya efektif, penerapan hukum pidana sebenarnya merupakan bentuk konkret kontrol negara untuk menjamin hak-hak konsumen dan menciptakan suasana ekonomi yang kondusif. Kedua, dalam kaitannya dengan penimbunan APD pada saat pandemi covod-19, hukum pidana bidang perlindungan konsumen sebenarnya dapat beperan lebih dari sekadar upaya terakhir (ultimum remedium), melainkan sebagai upaya prioritas utama (primum remedium). Hal ini dikarenakan sifat ketercelaan yang serius dalam tindakan penimbunan APD pada masa pandemi ini, sehingga dapat mengancam kelangsungan kehidupan manusia. Ketiga, dalam kajian hukum pidana bidang perlindungan konsumen, beberapa ketentuan terkait perlindungan konsumen dapat menjadi alternatif pilihan untuk menjerat para pelaku penimbun APD. Dalam artikel ini telah ditunjukkan, ketentuan dalam UU Perdagangan dan UU Persaingan Usaha sesungguhnya bisa diterapkan. Pada UU Perdagangan, ketentuan pidana dapat diimplementasikan dengan mengategorikan APD sebagai salah satu jenis barang penting. Sedangkan pada UU Persaingan Usaha, ketentuan tentang pelanggaran praktik monopoli dan persaingan usaha tidak sehat, antara lain berupa oligopoli, penetapan harga, kartel, monopoli, atau penguasaan pasar, dapat diberlakukan untuk menjerat para pelaku penimbunan APD pada masa pandemi. Agar memberi efekjera sekaligus langkah preventif, maka ketentuan pidana pokok dan pidana tambahan perlu diberlakukan secara bersamaan, dengan pertimbangan motif ekonomi dalam tindak pidana tersebut dan situasi pandemi yang tengah berlangsung.

\section{Daftar Pustaka}

\section{Artikel, Buku, dan Laporan}

Agustino, Daniel. "Karakteristik Harga dan Pengawasan KPPU terhadap Industri Oligopoli”. Jurnal Persaingan Usaha, 3 (2010): 3-26. 
Amrani, Hanafi. "Perlindungan Konsumen terhadap Praktik Bisnis Curang dan Upaya Penegakannya Melalui Sarana Hukum Pidana”. Negara Hukum, 6, 2 (2015): 187-204. DOI: 10.22212/jnh. v6i2.254.

Anggraini, Anna Maria Tri. "Penggunaan Bukti Ekonomi dalam Kartel Berdasarkan Hukum Persaingan Usaha”. Jurnal Hukum Prioris, 3, 3 (2013): 1-25.

Arief, Barda Nawawi. Bunga Rampai Kebijakan Hukum Pidana. Bandung: Citra Aditya Bakti, 1996.

Azizah. "Konsep Pengembangan Pendekatan Struktural dalam Perjanjian Penetapan Harga pada Putusan KPPU”. Jurnal Hukum dan Pembangunan, 43, 4 (2013): 514-528. DOI: 10.21143/jhp. vol43.no4.1498.

Barkatullah, Abdul Halim. Hak-Hak Konsumen. Bandung: Nusa Media, 2010.

Barkatullah, Abdul Halim. Perlindungan Hukum bagi Konsumen Transaksi E- Commerce Lintas Negara di Indonesia.Yogyakarta: FH UII Press, 2009.

Bemmelen, J.M.V. Hukum Pidana I: Hukum Pidana Materiel Bagian Umum. Bandung: Bina Cipta, 1984.

Bertens, K. Pengantar Etika Bisnis. Yogyakarta: Kanisius, 2000.

Charda S., Ujang. "Telaah Kritis terhadap Inkonsistensi Konsep Hubungan Kerja dalam Undang-Undang Nomor 13 Tahun 2003 tentang Ketenagakerjaan”. Jurnal Wawasan Hukum, 33, 2 (2015): 113-140. DOI: 10.25072 / jwy.v33i2.99.

Chazawi, Adami. Pelanggaran Hukum Pidana. Jakarta: PT. Raja GrafindoPersada, 2008.

Hamid, Edy Suandi. "Peran dan Intervensi Pemerintah dalam Perekonomian”. Jurnal Ekonomi Pembangunan, 4, 1 (1999): 41-58. DOI: 10.20885 / ejem.v4i1.6863.

Haveman, Roelof $\mathrm{H}$. The Legality of Adat Criminal Law in Modern Indonesia. Jakarta, Tata Nusa, 2002.

Hiariej, Eddy O.S. Prinsip-Prinsip Hukum Pidana. Yogyakarta: Cahaya Atma Pustaka, 2014.

Juaningsih, Imas Novita. "Penerapan Sanksi Pidana bagi Penimbun 
Masker di Indonesia Selama Masa Pandemi Covid-19”. 'Adalah: Buletin Hukum dan Keadilan, 4, 1 (2020): 75-80. DOI: 10.15408/ adalah.v4i1.15455.

Karsai, Krisztina. "Consumer Protection by Criminal Law". Dalam Ünnepi ekönyv Herczeg János professzor 70. Születésnapjára, diedit oleh Katona Tamás, 460-73. Szeged: Szegedi Tudományegyetem Állam- és Jogtudományi Kar, 2012.

Khalid, Afif. "Penafsiran Hukum oleh Hakim dalam Sistem Peradilan di Indonesia”. Al-Adl: Jurnal Hukum, VI, 11 (2014): 9-36. DOI: 10.31602/al-adl.v6i11.196.

Kompas.Com. "Cerita Gubernur Ganjar Kesal Ditawari Masker dan APD Harga Tak Wajar”. Https://nasional.kompas.com/ $\mathrm{read} / 2020$ / 05 / 09 / 16453841 / cerita-gubernur-ganjar-kesalditawari-masker-dan-apd-harga-tak-wajar, 9/5/2020. Diakses $10 / 6 / 2020$.

Liputan6.Com. "Ketua Pusat Krisis: PanicBuying Muncul karena Kecemasan Akan Wabah Corona COVID-19”. Https:/ / www. liputan6.com/health/ read/ 4208375 / ketua-pusat-krisis-panicbuying-muncul-karena-kecemasan-akan-wabah-corona-covid19, 22/3/2020. Diakses 10/6/2020.

Loqman, Loebby. "Hukum Pidana di Bidang Perekonomian”. Jurnal Hukum dan Pembangunan, 24, 5 (1994): 387-397. DOI: 10.21143/ jhp.vol24.no5.1050.

Lubis, Andi Fahmi, dkk. Hukum Persaingan Usaha: Buku Teks, diedit oleh Ningrum Natasya Sirait, Andi Fahmi Lubis, dan Helena Wirastri Wulandari. Jakarta: Komisi Pengawas Persaingan Usaha, 2017.

Mansyur, Ali dan Irsan Rahman. "Penegakan Hukum Perlindungan Konsumen Sebagai Upaya Peningkatan Mutu Produksi Nasional”. Jurnal Pembaharuan Hukum, 2, 1 (2015): 1-10. DOI: 10.26532/jph.v2i1.1411.

Mardiansyah, Rico. "Dinamika Politik Hukum dalam Pemenuhan Hak atas Kesehatan di Indonesia”. Veritas et Justitia, 4, 1 (2018): 227-251. DOI: 10.25123/vej.2918.

Mertokusumo, Sudikno. Mengenal Hukum. Yogyakarta: Universitas 
Atma Jaya Yogyakarta, 2010.

Miru, Ahmadi dan Sutarman Yado. Hukum Perlindungan Konsumen. Jakarta: RajaGrafindo Persada, 2004.

Muhammad, Rusli. Hukum Acara Pidana Kontemporer. Bandung: PT Citra Aditya Bakti, 2007.

Posner, Richard A. Economic Analysis of Law. Boston: Little Brown and Company, edisi keempat, 1992.

Prodjodikoro, Wirjono. Asas-asas Hukum Pidana di Indonesia.Bandung: Refika Aditama, 2003.

Reksodiputro, Mardjono. "Struktur Perekonomian Dewasa ini dan Permasalahan Korban”. Makalah Seminar Viktimologi, diselenggarakan oleh Universitas Airlangga, Surabaya, 28/10/1988.

Republik Indonesia, Badan Pengembangan dan Pembinaan Bahasa Kementerian Pendidikan dan Kebudayaan. Kamus Besar Bahasa Indonesia. Https: / / kbbi.kemdikbud.go.id. Diakses 28/6/2020.

Saleh, Roeslan. Stelsel Pidana Indonesia. Jakarta: Aksara Baru, 1983. Samsul, Inosentius. Perlindungan Konsumen: Kemungkinan Penerapan Tanggung Jawab Mutlak. Jakarta: Pascasarjana Fakultas Hukum Universitas Indonesia, 2004.

Serambinews.Com. "Vaksin Corona Masih Belum Ditemukan, Ini yang Terjadi di Dunia Jika Covid-19 Tak Bisa Dihentikan". Https: / / aceh.tribunnews.com / 2020/05 / 08/vaksin-coronamaih-belum-ditemukan-ini-yang-akan-terjadi-di-dunia-jikacovid-19-tak-bisa-dihentikan, 8/5/2020. Diakses 10/6/2020.

Shofie, Yusuf. Perlindungan Konsumen dan Instrumen-intrumen Hukumnya. Bandung: Citra Aditya Bakti, cetakan kedua, 2003.

Sidabolok, Janus. Hukum Perlindungan Konsumen di Indonesia. Bandung: PT. Citra Aditya Bakti, 2010.

Soeroso, R. Pengantar Ilmu Hukum. Jakarta: Sinar Grafika, 1996.

Suara.Com. "Pandemi Covid-19: Jumlah APD Kurang, Tenaga Medis Rentan Terserang". Https://www.suara.com/ yoursay / 2020/04/22 / 095442 / pandemi-covid-19-jumlah-apdkurang-tenaga-medis-rentan-terserang, 22/4/2020. Diakses $10 / 6 / 2020$. 
Susilo, Adityo, dkk. "Corona Virus Deases 2019: Tinjauan Literatur Terkini”. Jurnal Penyakit Dalam Indonesia, 7, 1 (2020): 45-67. DOI: 10.7454/jpdi.v7i1.415.

Utrecht, E. Hukum Pidana I. Surabaya: Pustaka Tinta Mas, 1986.

VOAIndonesia.Com. "Stok APD Langka, Pekerja Medis di Sejumlah Daerah Pakai Jas Hujan”. Https:/ / www.voaindonesia.com/a/ stok-apd-langka-pekerja-medis-di-sejumlah-daerah-pakai-jashujan/5356660.html, 2/4/2020. Diakses 29/6/2020.

Waluyadi. Hukum Pidana Indonesia. Jakarta: Djambatan, 2003.

Widayati, Lidya Suryani. "Ultimum Remedium dalam Bidang Lingkungan Hidup”. Jurnal Hukum Ius Quia Iustum, 22, 1 (2015): 1-24. DOI: 10.20885 /iustum.vol22.iss1.art1.

World Health Organization. "WHO Timeline-COVID-19”. Https: / / www.who.int/news-room/ detail/ 27-04-2020-who-timeline--covid-19, 27/4/2020. Diakses 10/6/2020.

\section{Peraturan Hukum}

Republik Indonesia. Undang-Undang Dasar Negara Republik Indonesia Tahun 1945.

Republik Indonesia. Undang-Undang Nomor 5 Tahun 1999 tentang Larangan Praktek Monopoli dan Persaingan Usaha Tidak Sehat. Lembaran Negara Tahun 1999 Nomor 33, Tambahan Lembaran Negara Nomor 3817.

Republik Indonesia. Undang-Undang Nomor 8 Tahun 1999 tentang Perlindungan Konsumen. Lembaran Negara Tahun 1999 Nomor 42, Tambahan Lembaran Negara Nomor 3821.

Republik Indonesia. Undang-Undang Nomor 7 Tahun 2014 tentang

Perdagangan. Lembaran Negara Tahun 2014 Nomor 45, Tambahan Lembaran Negara Nomor 5512.

Republik Indonesia. Peraturan Presiden Nomor 71 Tahun 2015 tentang Penetapan dan Penyimpanan Barang Kebutuhan Pokok dan Barang Penting. Lembaran Negara Tahun 2015 Nomor 138.

Republik Indonesia, Kementerian Kesehatan. Peraturan Menteri Nomor 52 Tahun 2018 tentang Keselamatan dan Kesehatan 
Penimbunan Alat Pelindung Diri pada Masa Pandemi Covid-19

Kerja di Fasilitas Pelayanan Kesehatan. Berita Negara Tahun 2019 Nomor 19. 